\title{
LIQUEFACTION OF NİĞDE-ULUKIŞLA OIL SHALE: THE EFFECTS OF PROCESS PARAMETERS ON THE CONVERSION OF LIQUEFACTION PRODUCTS
}

\author{
OZLEM ESEN KARTAL ${ }^{(a) *}$, SERHAT AKIN ${ }^{(b)}$, \\ BERNA HASÇAKIR $^{(\mathrm{c})}$, HÜSEYIN KARACA ${ }^{(\mathrm{a})}$ \\ (a) Department of Chemical Engineering, Inonu University, 44280, Malatya, Turkey \\ (b) Department of Petroleum and Natural Gas Engineering, METU, 06531, Ankara, Turkey

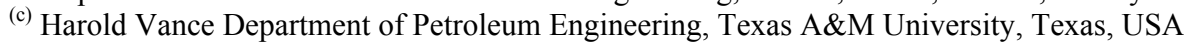

\begin{abstract}
In this paper, the direct liquefaction of Turkish Niğde-Ulukışla oil shale in noncatalytic and catalytic conditions was studied. The effects of pressure, tetralin/oil shale ratio, catalyst type and concentration, reaction time and temperature and oil shale/waste paper ratio on the process were investigated. It was found that tetralin/oil shale ratio had no considerable effect on the total and liquefaction products conversions under the noncatalytic conditions. $\mathrm{Fe}_{2} \mathrm{O}_{3}, \mathrm{MoO}_{3}, \mathrm{Mo}(\mathrm{CO})_{6}, \mathrm{Cr}(\mathrm{CO})_{6}$ and zeolite were used as catalysts in catalytic liquefaction. The highest total and liquefaction products conversions were obtained using $\mathrm{MoO}_{3}$ as catalyst at a concentration of $9 \%$ by weight. Reaction temperature of $400{ }^{\circ} \mathrm{C}$ and reaction time of 90 minutes were chosen according to obtained liquefaction results. Co-liquefaction experiments were performed using waste paper. Both the total and oil + gas conversions were increased to a considerable extent by the application of the co-liquefaction process. According to gas chromatographic-mass spectrometric (GC-MS) analysis, the liquid product from the liquefaction process of oil shale under catalytic conditions of experiment 22 consisted mainly of naphthalene and its derivatives and polycyclic hydrocarbon such as indene and its derivatives.
\end{abstract}

Keywords: oil shale liquefaction, total conversion, liquefaction products, Niğde-Ulukişla.

\section{Introduction}

The world energy demand has increased sharply in recent decades with an ongoing economic growth of community. The fossil fuels currently provide over $80 \%$ of the world's energy consumption, but it is expected that their reserves will diminish within this century. As a result, production of

\footnotetext{
* Corresponding author: e-mail ozlem.kartal@inonu.edu.tr
} 
alternative liquid fuels should be developed to meet global energy demand. Coal liquefaction technology applied either directly or indirectly is considered to be a promising method for the production of liquid fuels, as well as chemical feedstock [1-3]. Similarly to coal liquefaction technology, oil shale can also be converted to liquid fuels and feedstock for the production of chemicals.

Oil shale is a sedimentary rock consisting of organic matter in its mineral matrix. Kerogen is a major organic matter of oil shale and is a cross-linked macromolecule of mainly carbon, hydrogen and oxygen. Shale oil, considered as an alternative fuel for crude oil, is obtained from kerogen [4]. Since total world proven reserves of oil shale are approximately 80 billion tons, it is regarded as an alternative source of liquid fuel [5]. Oil shale has higher atomic $\mathrm{H} / \mathrm{C}$ ratio than lignite due to its lower rank $[6,7]$. Thus, the addition of hydrogen to the reaction medium, which mainly determines the cost of liquefaction processes, could be minimized by use of oil shale in these processes. As a result, much of the research has been focused on the possibility of liquefaction of oil shale by pyrolysis [8-14], co-pyrolysis [15-21], supercritical fluid extraction (SFE) [5, 22-24] and retorting [25-29].

Turkey has 3 to 5 billion tons of estimated oil shale reserves located in the middle and western parts of Anatolia and detailed studies on oil shale potentials of Turkey for production of liquid fuels are reported in literature [30-33]. Since oil shale deposits of Turkey constitute the second largest fossil fuels after lignite, the conversion of oil shale to liquid fuels as an alternative to petroleum becomes an important process. Metecan et al. [34] studied the effect of pyrite catalyst on the hydroliquefaction of Göynük oil shale. The researchers reported that the maximum conversion and yield of extract were observed at $400{ }^{\circ} \mathrm{C}$ with and without pyrite catalyst in the presence of toluene. Pyrite catalyst exerted a considerable effect on those below $400{ }^{\circ} \mathrm{C}$ and caused an increase of the amount of hydrocarbons in gaseous products and a decrease of the molecular weight of oils at $450{ }^{\circ} \mathrm{C}$. Olukcu et al. [35] examined the liquefaction of Beypazarı oil shale by pyrolysis, one of the oldest liquefaction techniques used, to produce liquid fuels (named as syncrude) from solid fossils and found that in free-falling pyrolysis the maximum conversion was $61.9 \%$ at $873 \mathrm{~K}$, whereas in conventional pyrolysis it was $50.5 \%$ at $798 \mathrm{~K}$. Compared with free-falling pyrolysis during which the cracking reaction took place to a greater degree, conventional pyrolysis yielded less $n$-alkenes at the same temperature, $798 \mathrm{~K}$. Ballice [36] investigated the effect of the mineral matter of Beypazarı oil shale on the pyrolysis yield and product composition. It is reported that removal of the material soluble in $\mathrm{HCl}$ and $\mathrm{HNO}_{3}$ affected the conversion of organic materials whereas the leaching of pyrites with $\mathrm{HNO}_{3}$ did not cause a change in the reactivity of the organic material during pyrolysis.

Although a number of studies have been carried on the production of solid, liquid and gaseous products from oil shale, more attention should be 
paid to the liquefaction of oil shale due to the dependence of process yield on several factors such as oil shale rank and process parameters. The purpose of this study is to carry out the direct liquefaction of Niğde-Ulukışla oil shale under both noncatalytic and catalytic conditions in a nitrogen gas atmosphere and to investigate the effects of parameters, including tetralin/oil shale ratio, catalyst type and concentration, reaction time and temperature and waste paper amount, on the process. Besides, oils, which are liquid products obtained from the liquefaction process as solubles in hexane, are also analyzed qualitatively to determine their composition.

\section{Experimental}

Niğde-Ulukışla oil shale and waste paper used in this study were first ground and dried in the laboratory atmosphere. The results of proximate and ultimate analyses of both are given in Table 1.

The liquefaction reactions were carried out in a $500 \mathrm{ml}$ batch autoclave with a motor driven stirrer (PARR Brand Model 4575, USA) in the presence of tetralin used as solvent under both noncatalytic and catalytic conditions in a nitrogen gas atmosphere (Fig. 1).

The reaction temperature was maintained with $\pm 2{ }^{\circ} \mathrm{C}$ accuracy. Commercially available $\mathrm{Fe}_{2} \mathrm{O}_{3}, \mathrm{MoO}_{3}, \mathrm{Mo}(\mathrm{CO})_{6}, \mathrm{Cr}(\mathrm{CO})_{6}$ and zeolite were used without further treatment to compare their catalytic activities in catalytic experiments. Figure 2 shows the flowchart of the experimental procedure.

Table 1. Proximate and ultimate analyses of oil shale and waste paper samples

\begin{tabular}{|l|c|c|}
\hline & Niğde-Ulukışla oil shale & Waste paper \\
\hline Proximate analysis, wt\% as used & & \\
Moisture & 4.00 & 2.60 \\
Ash & 69.91 & 5.88 \\
Volatile matter & 17.41 & 80.00 \\
Fixed carbon & & 11.52 \\
Total sulphur & 8.68 & - \\
Ultimate analysis, wt\% daf & 2.13 & \\
$\mathrm{C}$ & & 43.43 \\
$\mathrm{H}$ & 10.04 & 5.76 \\
$\mathrm{~N}$ & 1.22 & - \\
$\mathrm{S}$ & - & 0.09 \\
$\mathrm{O}^{\mathrm{a}}$ & 0.27 & 50.72 \\
\hline
\end{tabular}

a - by difference; daf - dry ash free 


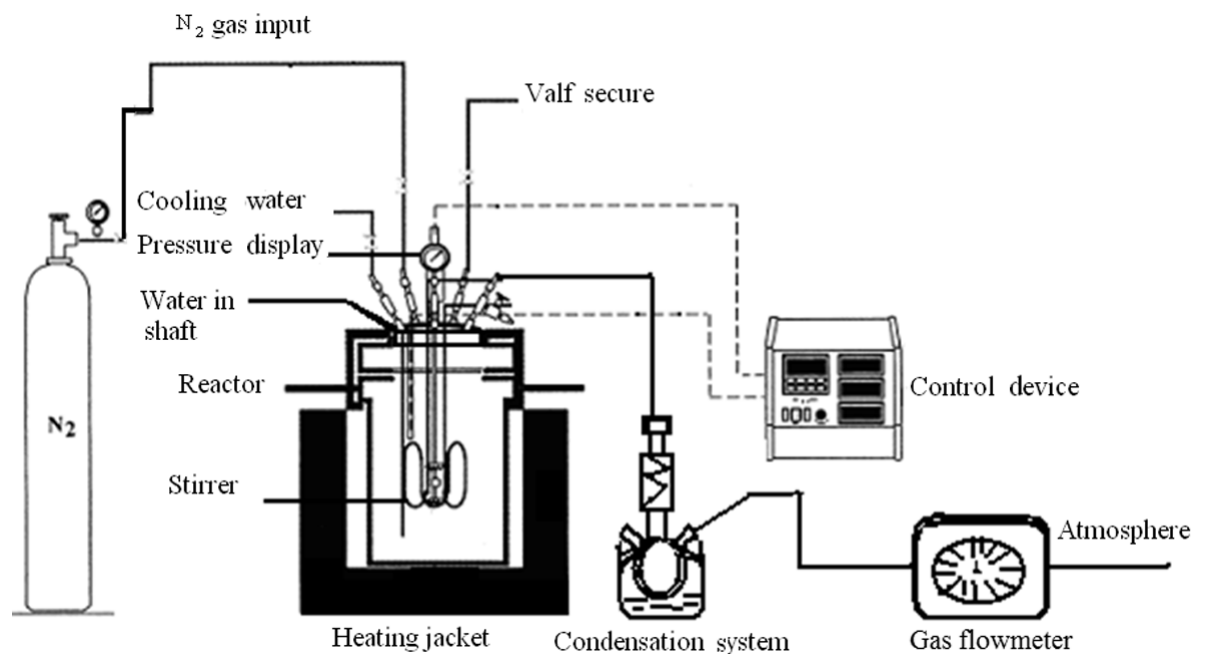

Fig. 1. The experimental set-up.

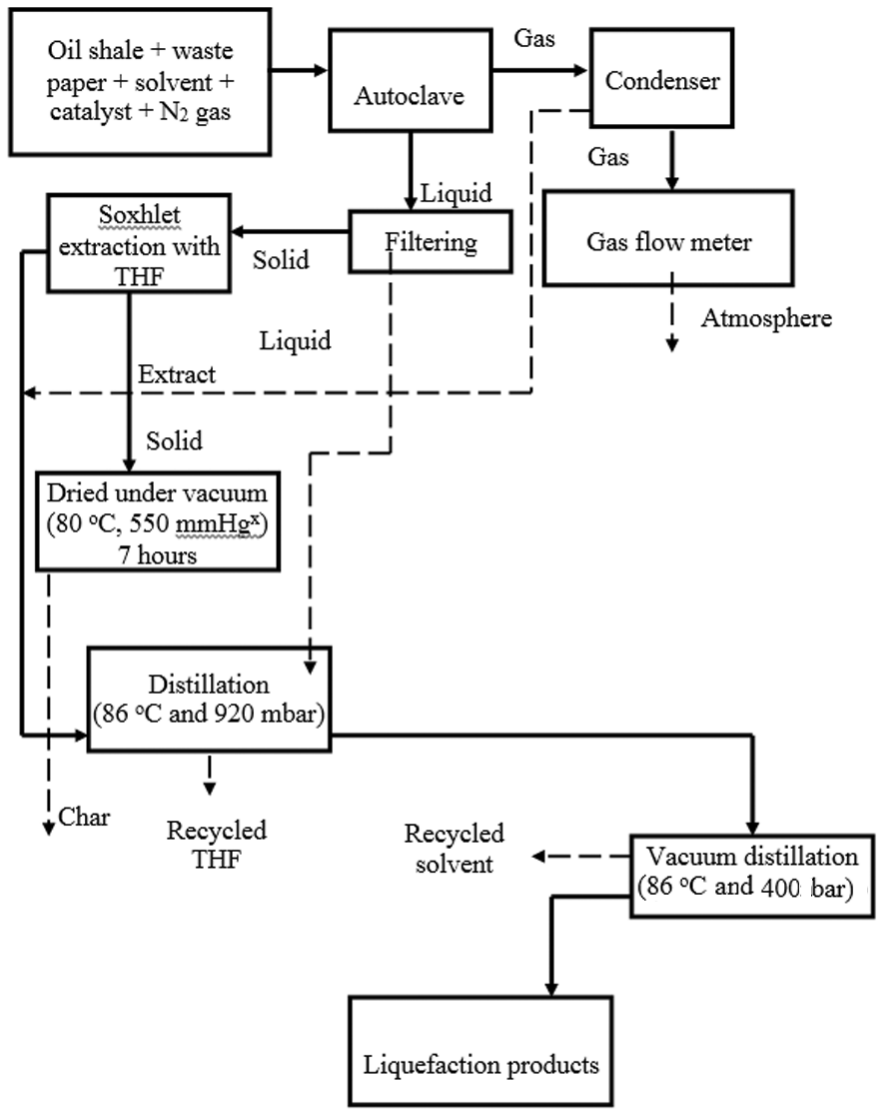

Fig. 2. Flowchart of the experimental procedure. 
$30 \mathrm{~g}$ of oil shale and a prescribed amount of tetralin were charged into the autoclave and then purged and pressurized to 50 bar with a flow of nitrogen at room temperature. In the liquefaction experiments conducted in the presence of catalyst or waste paper the prescribed amounts of both were also added to the autoclave. The content of autoclave was heated to the reaction temperature for about 1 hour with stirring. After each run, the autoclave was immediately cooled. The solid and liquid products were removed from the reactor carefully and solids obtained by filtration were analyzed by successive solvent extraction. The liquid products obtained from the liquefaction process were separated into oils (hexane soluble), asphaltene (toluene soluble but hexane insoluble) and preasphaltene (THF soluble but toluene insoluble), depending on the differences in their solubility. The total conversions were calculated according to char yields, while preasphaltene (PAS), asphaltene (AS) and oil + gas conversions were calculated according to the results of solvent extraction processes. The char yields and conversions were calculated by the use of Equations (1)-(5) given below.

Specifically, char yield was described as follows:

$$
\text { Char (daf) \% = char (daf, g)/sample (daf, g) } \times 100 \text {. }
$$

Equation (2) was used to calculate total conversion (liquefaction products + gas):

$$
\text { Total conversion } \%=100-\text { char } \% \text { (daf). }
$$

The conversion of liquefaction products, preasphaltene and asphaltene, was calculated by Equations (3) and (4), respectively:

$$
\begin{gathered}
\text { PAS } \%=\text { PAS }(\mathrm{g}) / \text { sample }(\text { daf, } g) \times 100, \\
\text { AS } \%=\text { AS }(g) / \text { sample }(\text { daf, g) } \times 100 .
\end{gathered}
$$

The calculation of conversion of oil + gas was done as follows:

$$
(\mathrm{Oil}+\text { gas) } \%=\text { total conversion } \% \text { (daf) }-\mathrm{PAS} \%-\mathrm{AS} \% \text {. }
$$

The noncatalytic and catalytic conditions of liquefaction of NiğdeUlukışla oil shale determined by considering the process parameters such as tetralin/oil shale ratio, catalyst type and concentration, reaction time and temperature and oil shale/waste paper ratio are given in Table 2.

Gas chromatography-mass spectrometry (GC-MS) analysis of oils was carried out by an Agilent $6890 \mathrm{~N}$ Network model gas chromatograph equipped with an Agilent 5973 model mass spectrometer. The product distributions were conducted using a DB-1701 capillary column $(30 \mathrm{~m} \times$ $0.25 \mathrm{~mm}, 0.25 \mu \mathrm{m}$ film thickness) in the presence of helium as a carrier gas at a flow rate of $5 \mathrm{mldk}^{-1}$. The column was held at $60{ }^{\circ} \mathrm{C}$ for $1 \mathrm{~min}$ and then heated to $240{ }^{\circ} \mathrm{C}$ at a rate of $4{ }^{\circ} \mathrm{C} \cdot \mathrm{min}^{-1}$ and finally held isothermal for $10 \mathrm{~min}$. The injector temperature was $250^{\circ} \mathrm{C}$ and injection volume $1 \mu 1$. 
Table 2. Noncatalytic and catalytic conditions of the liquefaction process (particle size $-250,+125 \mu \mathrm{m}$, stirring speed 800 rpm)

\begin{tabular}{|c|c|c|c|c|c|c|c|}
\hline $\begin{array}{l}\text { Exp. } \\
\text { No }\end{array}$ & $\begin{array}{c}\text { Pressure, } \\
\text { bar }\end{array}$ & $\begin{array}{l}\text { Tetralin/ } \\
\text { oil shale }\end{array}$ & $\begin{array}{c}\text { Catalyst } \\
\text { type }\end{array}$ & $\begin{array}{l}\text { Catalyst } \\
\text { con., wt } \%\end{array}$ & $\begin{array}{r}\text { Time, } \\
\min \\
\end{array}$ & $\begin{array}{c}\text { Temperature, } \\
{ }^{\circ} \mathrm{C}\end{array}$ & $\begin{array}{c}\text { Oil shale/ } \\
\text { waste paper }\end{array}$ \\
\hline \multicolumn{8}{|c|}{ Effect of pressure } \\
\hline 1 & 0 & 3 & - & - & 60 & 400 & - \\
\hline 2 & 25 & 3 & - & - & 60 & 400 & - \\
\hline 3 & 50 & 3 & - & - & 60 & 400 & - \\
\hline 4 & 75 & 3 & - & - & 60 & 400 & - \\
\hline \multicolumn{8}{|c|}{ Effect of solvent/oil shale ratio } \\
\hline 5 & 50 & 1 & - & - & 60 & 400 & - \\
\hline 3 & 50 & 3 & - & - & 60 & 400 & - \\
\hline 6 & 50 & 6 & - & - & 60 & 400 & - \\
\hline 7 & 50 & 9 & - & - & 60 & 400 & - \\
\hline \multicolumn{8}{|c|}{ Effect of catalyst type } \\
\hline 8 & 50 & 3 & $\mathrm{Fe}_{2} \mathrm{O}_{3}$ & 3 & 60 & 400 & - \\
\hline 9 & 50 & 3 & $\mathrm{MoO}_{3}$ & 3 & 60 & 400 & - \\
\hline 10 & 50 & 3 & $\mathrm{Mo}(\mathrm{CO})_{6}$ & 3 & 60 & 400 & -- \\
\hline 11 & 50 & 3 & $\mathrm{Cr}(\mathrm{CO})_{6}$ & 3 & 60 & 400 & - \\
\hline 12 & 50 & 3 & Zeolite & 3 & 60 & 400 & - \\
\hline \multicolumn{8}{|c|}{ Effect of catalyst concentration } \\
\hline 13 & 50 & 3 & - & 0 & 60 & 400 & - \\
\hline 9 & 50 & 3 & $\mathrm{MoO}_{3}$ & 3 & 60 & 400 & - \\
\hline 14 & 50 & 3 & $\mathrm{MoO}_{3}$ & 6 & 60 & 400 & - \\
\hline 15 & 50 & 3 & $\mathrm{MoO}_{3}$ & 9 & 60 & 400 & - \\
\hline \multicolumn{8}{|c|}{ Effect of reaction time } \\
\hline 16 & 50 & 3 & $\mathrm{MoO}_{3}$ & 9 & 30 & 400 & \\
\hline 15 & 50 & 3 & $\mathrm{MoO}_{3}$ & 9 & 60 & 400 & - \\
\hline 17 & 50 & 3 & $\mathrm{MoO}_{3}$ & 9 & 90 & 400 & - \\
\hline 18 & 50 & 3 & $\mathrm{MoO}_{3}$ & 9 & 150 & 400 & - \\
\hline \multicolumn{8}{|c|}{ Effect of reaction temperature } \\
\hline 19 & 50 & 3 & $\mathrm{MoO}_{3}$ & 9 & 90 & 350 & - \\
\hline 20 & 50 & 3 & $\mathrm{MoO}_{3}$ & 9 & 90 & 375 & - \\
\hline 17 & 50 & 3 & $\mathrm{MoO}_{3}$ & 9 & 90 & 400 & - \\
\hline 21 & 50 & 3 & $\mathrm{MoO}_{3}$ & 9 & 90 & 425 & - \\
\hline \multicolumn{8}{|c|}{ Effect of oil shale/waste paper ratio } \\
\hline 22 & 50 & 3 & $\mathrm{MoO}_{3}$ & 9 & 90 & 400 & 1 \\
\hline 23 & 50 & 3 & $\mathrm{MoO}_{3}$ & 9 & 90 & 400 & 2 \\
\hline 24 & 50 & 3 & $\mathrm{MoO}_{3}$ & 9 & 90 & 400 & 3 \\
\hline 25 & 50 & 3 & $\mathrm{MoO}_{3}$ & 9 & 90 & 400 & 4 \\
\hline
\end{tabular}

The abbreviations used: Exp. - Experiment; con. - concentration.

\section{Results and discussion}

\subsection{Effect of pressure}

Although hydrogen gas is used to increase the conversion of liquid products in coal liquefaction processes, it can be provided from both the coal and the hydrogen-donor solvent so that coal can be liquefied under nitrogen gas [37]. In this study, the liquefaction of Niğde-Ulukışla oil shale was conducted 
under nitrogen gas and as can be seen from Figure 3, the total and oil + gas conversion values increased at pressures between 0 and 50 bar but then they decreased slightly at pressures up to 75 bar. This behavior can be attributed to an effective penetration of the solvent through oil shale pores with pressure. But at higher pressure, the diffusion of liquefaction products formed in the pores can be prevented, as a result, a slight decrease in both conversions was observed and the optimum pressure was determined as 50 bar.

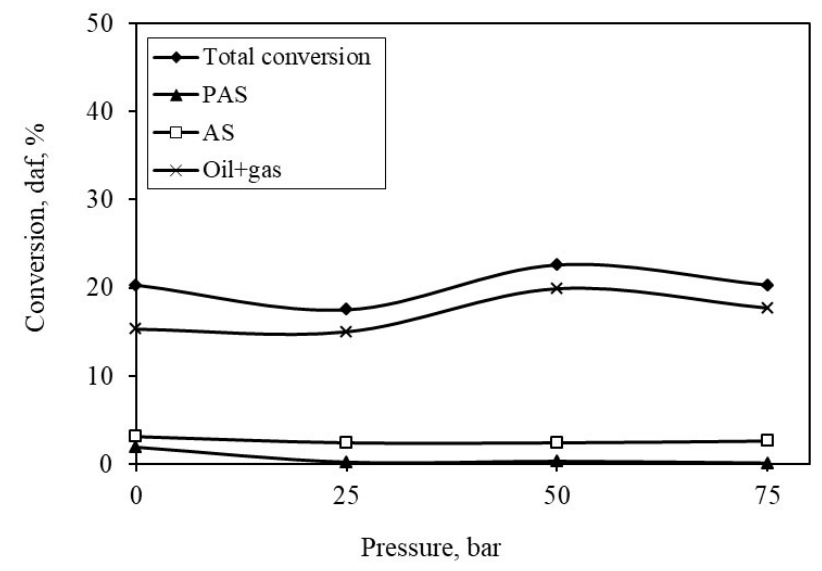

Fig. 3. Effect of initial nitrogen pressure on the liquefaction products conversion in the noncatalytic liquefaction of Niğde-Ulukışla oil shale. (The abbreviation used: daf - dry ash free.)

\subsection{Effect of tetralin/oil shale ratio}

The ratio of solvent/solid affects both total and liquefaction products conversions, as well as the cost of oil shale liquefaction process, which rises upon increasing this ratio. In recent decades, the cost of a barrel of liquefaction product obtained by coal liquefaction has been calculated to be approximately $\$ 50$ and it is noteworthy that this cost mainly depends on solvent/solid ratio. This ratio also determines the hydrogen availability [38]. In this study, tetralin having a hydrogen-donating function was used as solvent and the experiments were conducted by changing the tetralin/oil shale ratio from 1/1 to $9 / 1$. One can see from Figure 4 that there was a slight increase in the total and oil + gas conversions at a tetralin/oil shale ratio of $3 / 1$, while no considerable change took place when this ratio was increased. In catalytic liquefaction processes, a high ratio of solvent/solid was not preferred. This is because the existence of excess tetralin may obscure the effect of the added catalysts as the solvent itself is a strong H-donor [37]. Taking into consideration the volume of the reactor and total conversion values, the optimum corresponding ratio was selected as $3 / 1$. 


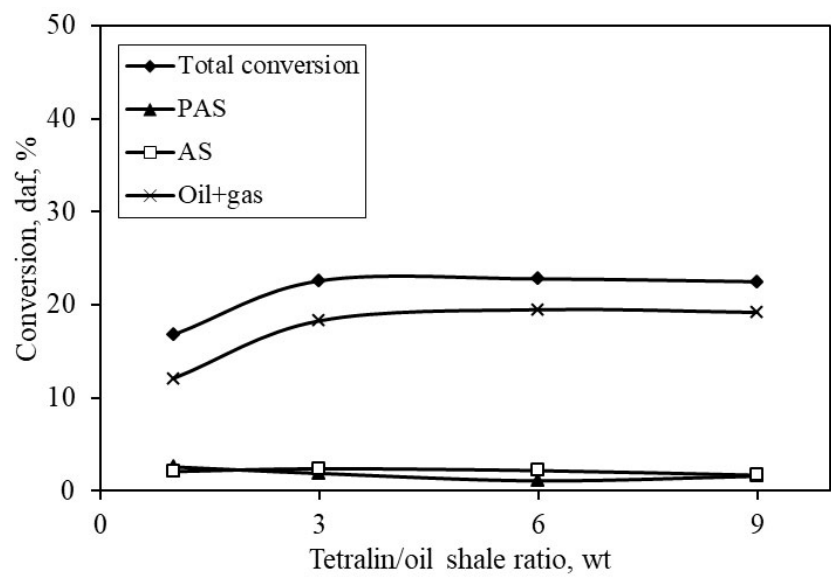

Fig. 4. Effect of tetralin/oil shale ratio on the liquefaction products conversion in the noncatalytic liquefaction of Niğde-Ulukışla oil shale. (The abbreviation used: daf dry ash free.)

\subsection{Effect of catalyst type and concentration}

Application of suitable catalysts for direct coal liquefaction appears to improve total conversion and product selectivity by enhancing coal dissolution. A number of catalytic materials have been investigated for their suitability for coal liquefaction [3, 39, 40]. In this study, the catalytic liquefaction of Niğde-Ulukışla oil shale was performed using five different catalysts, namely $\mathrm{Fe}_{2} \mathrm{O}_{3}, \mathrm{MoO}_{3}, \mathrm{Mo}(\mathrm{CO})_{6}, \mathrm{Cr}(\mathrm{CO})_{6}$ and zeolite, to identify a suitable catalyst in terms of cost and environmental aspects. The data shown in Figure 5 indicate that the total conversion of oil shale attained in

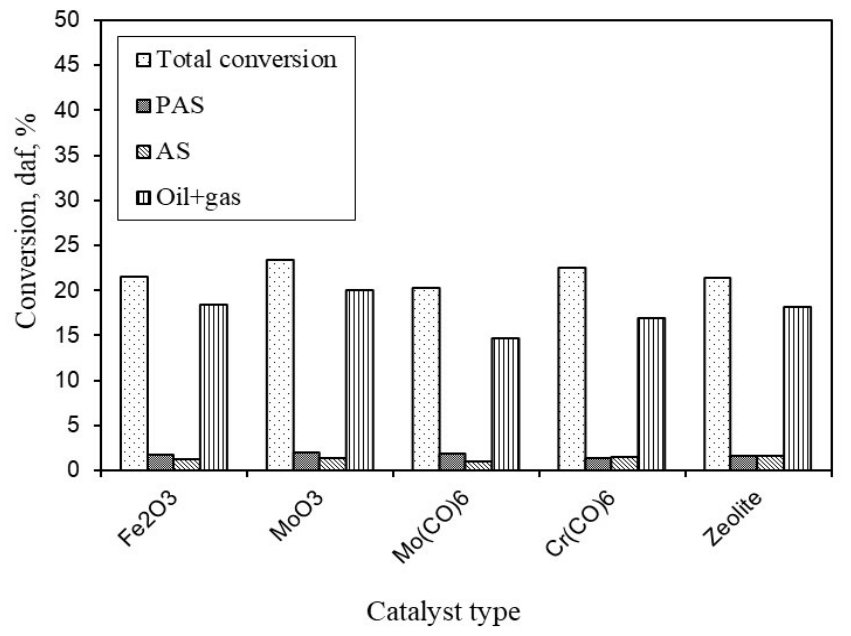

Fig. 5. Effect of catalyst type on the liquefaction products conversion in the catalytic liquefaction of Niğde-Ulukışla oil shale. (The abbreviation used: daf - dry ash free.) 
noncatalytic liquefaction was $22.6 \%$, being $23.4 \%$ in catalytic liquefaction at a $3 \% \mathrm{MoO}_{3}$ concentration. The order of activity of the tested catalysts for the oil + gas conversion may be given as $\mathrm{MoO}_{3}>\mathrm{Cr}(\mathrm{CO})_{6}>\mathrm{Fe}_{2} \mathrm{O}_{3}=$ zeolite $>$ $\mathrm{Mo}(\mathrm{CO})_{6}$. As can be seen from Figure 6, an increase in catalyst concentration from 3 to $9 \%$ led to a rise in the total and oil + gas conversions from 23.4 to $30.1 \%$ and from 20.0 to $26.5 \%$, respectively. Therefore, by considering the conversion values obtained the optimum catalyst concentration was found to be $9 \%$.

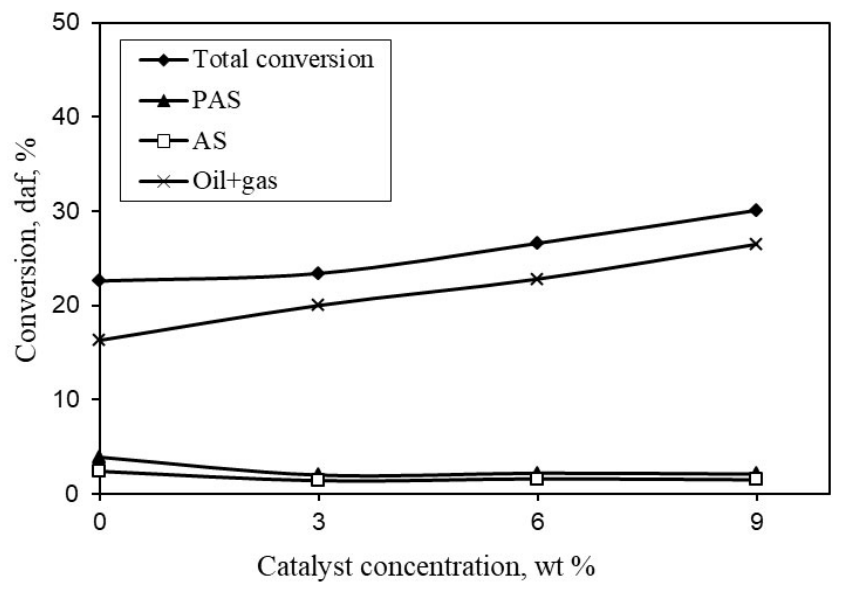

Fig. 6. Effect of catalyst concentration on the liquefaction products conversion in the catalytic liquefaction of Niğde-Ulukışla oil shale. (The abbreviation used: daf - dry ash free.)

\subsection{Effect of reaction time}

In coal liquefaction process, both the reaction temperature and time are vital parameters. To examine the effect of reaction time ranging from 30 to $150 \mathrm{~min}$, the experiments were carried out in the presence of $\mathrm{MoO}_{3}$ catalyst at a concentration of $9 \%$. The reactor was heated for about 1 hour to reach the determined reaction temperature, so the formation of radicals by decomposition of oil shale and the transfer of hydrogen to them during this heatingup period would result in the launch of the liquefaction process without attaining the desired reaction temperature. That is why it is impossible to determine the reaction time precisely. As can be seen from Figure 7, the total conversion slightly increased from 28.6 to $31.1 \%$ with an increase in the reaction time from $30 \mathrm{~min}$ to $90 \mathrm{~min}$ and then remained unchanged. Since a certain amount of time (60-90 min) is necessary for formation of radicals and obtaining a high yield of a light liquid product, i.e. oils, the reaction time was selected to be 90 minutes [1,37]. 


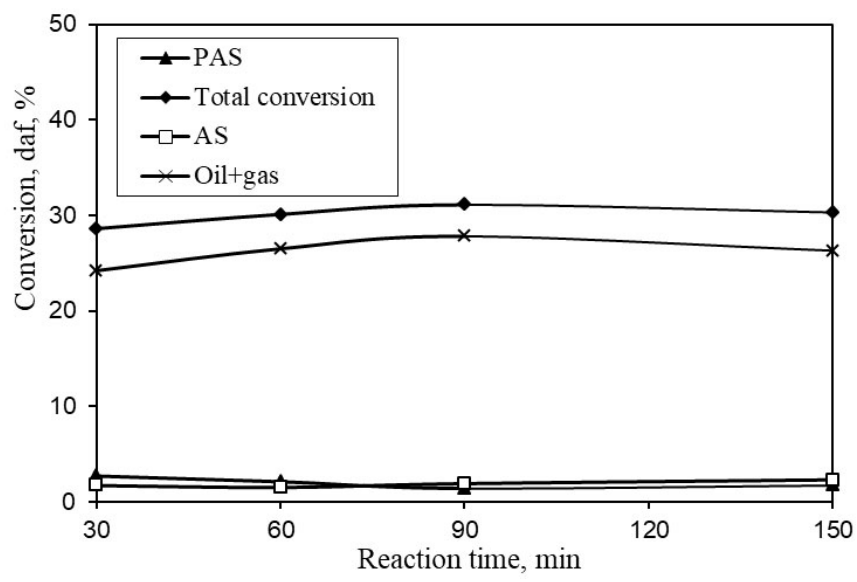

Fig. 7. Effect of reaction time on the liquefaction products conversion in the catalytic liquefaction of Niğde-Ulukışla oil shale. (The abbreviation used: daf - dry ash free.)

\subsection{Effect of reaction temperature}

In this study, the catalytic liquefaction of Niğde-Ulukışla oil shale in the presence of $\mathrm{MoO}_{3}$ catalyst at a concentration of $9 \%$ was carried out in the reaction temperature range of $350-425{ }^{\circ} \mathrm{C}$ during 90 minutes, to determine its effect on the process. It is accepted that the yield of liquid products should be high and that of gaseous products low to produce fuels alternative to petroleum. It is clearly evident from Figure 8 that as the temperature increased from $350{ }^{\circ} \mathrm{C}$ to $400{ }^{\circ} \mathrm{C}$, the total conversion increased from 22.7

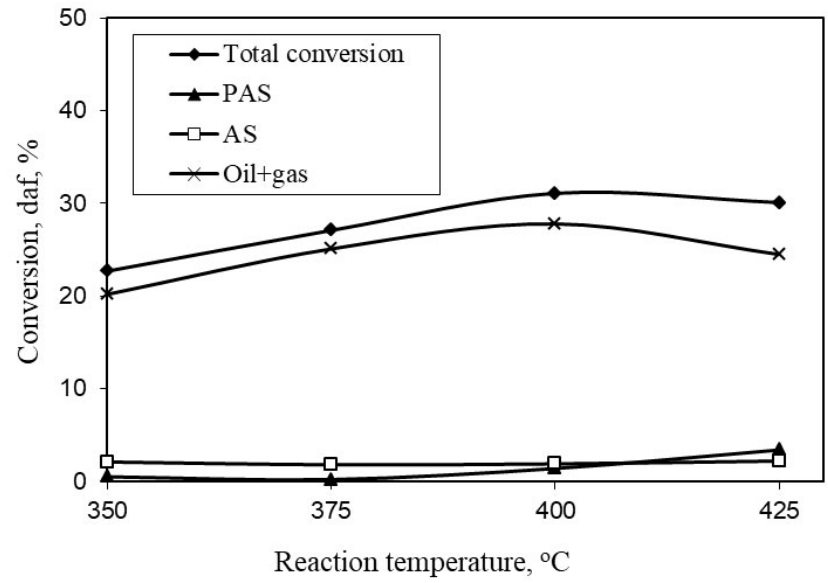

Fig. 8. Effect of reaction temperature on the liquefaction products conversion in the catalytic liquefaction of Niğde-Ulukışla oil shale. 
to $31.1 \%$. However, a further increase in temperature, i.e. from $400{ }^{\circ} \mathrm{C}$ to $425^{\circ} \mathrm{C}$, had no considerable effect on the total conversion. Stabilization of radicals formed during liquefaction either by taking hydrogen atoms from reaction medium or combining them with other radicals causes an increase in total conversion. But as temperature increases, formation of radicals decreases and as a result, total conversion does not increase significantly $[21,41]$. Besides, as both liquid products and unreacted solid material are oxidized at higher temperatures, the yield of gaseous products is enhanced [42]. Based on these results the effective reaction temperature was selected as $400{ }^{\circ} \mathrm{C}$.

\subsection{Effect of oil shale/waste paper ratio}

Since biomass from agriculture and wood residues, as well as municipal solid waste and energy crops is found plentifully, it is worthwhile to achieve liquefaction of oil shale with biomass in order to promote the total conversion and production of lighter products and decrease the cost of the liquefaction process [43]. In this study, the co-liquefaction of Niğde-Ulukışla oil shale with waste paper was performed at $400{ }^{\circ} \mathrm{C}$ in the presence of $\mathrm{MoO}_{3}$ catalyst during 90 minutes of reaction time. The contribution of waste paper at different oil shale/waste paper ratios to total conversion in the liquefaction process is shown in Figure 9. It is noteworthy that co-liquefaction was very effective at an oil shale/waste paper ratio of $1 / 1$, providing $80.5 \%$ of total conversion as compared with $31.1 \%$ attained without using waste paper. It is evident that co-liquefaction of Niğde-Ulukışla oil shale with waste paper enabled an increase of both the total and oil + gas conversions via synergy effect.

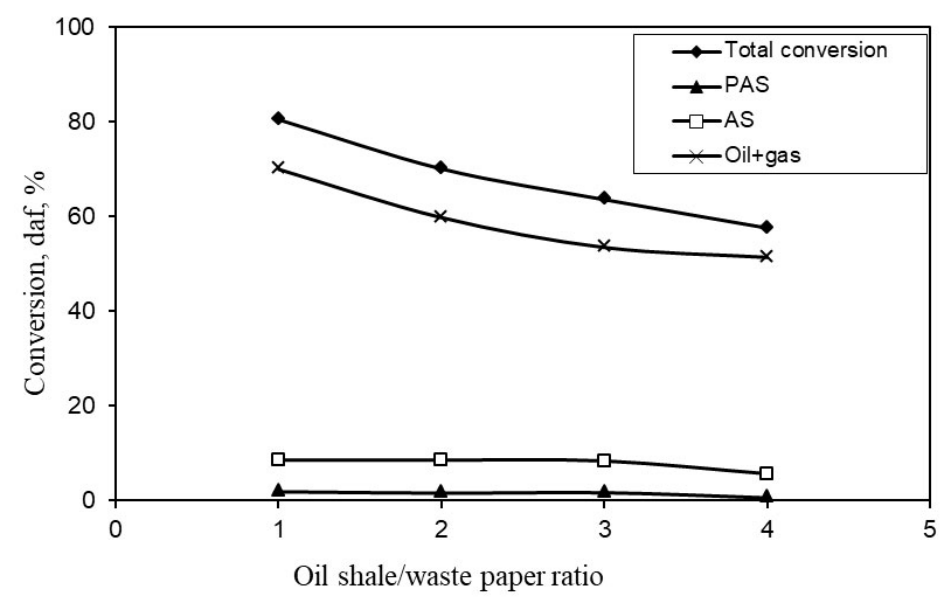

Fig. 9. Effect of oil shale/waste paper ratio on the liquefaction products conversion in the catalytic liquefaction of Niğde-Ulukışla oil shale. 


\subsection{GC-MS analysis of oils}

Figure 10 shows a typical GC-MS chromatogram of oil obtained as a liquid product from the liquefaction process of oil shale under catalytic conditions of experiment 22. This liquid product is soluble in hexane. Table 3 lists compounds attributable to the 18 peaks observed in the GC-MS chromatogram. According to the GC-MS analysis, naphthalene and its derivatives and polycyclic hydrocarbon such as indene and its derivatives as the main components accounted for $50 \%$ and approximately $20 \%$ of the liquid product, respectively.

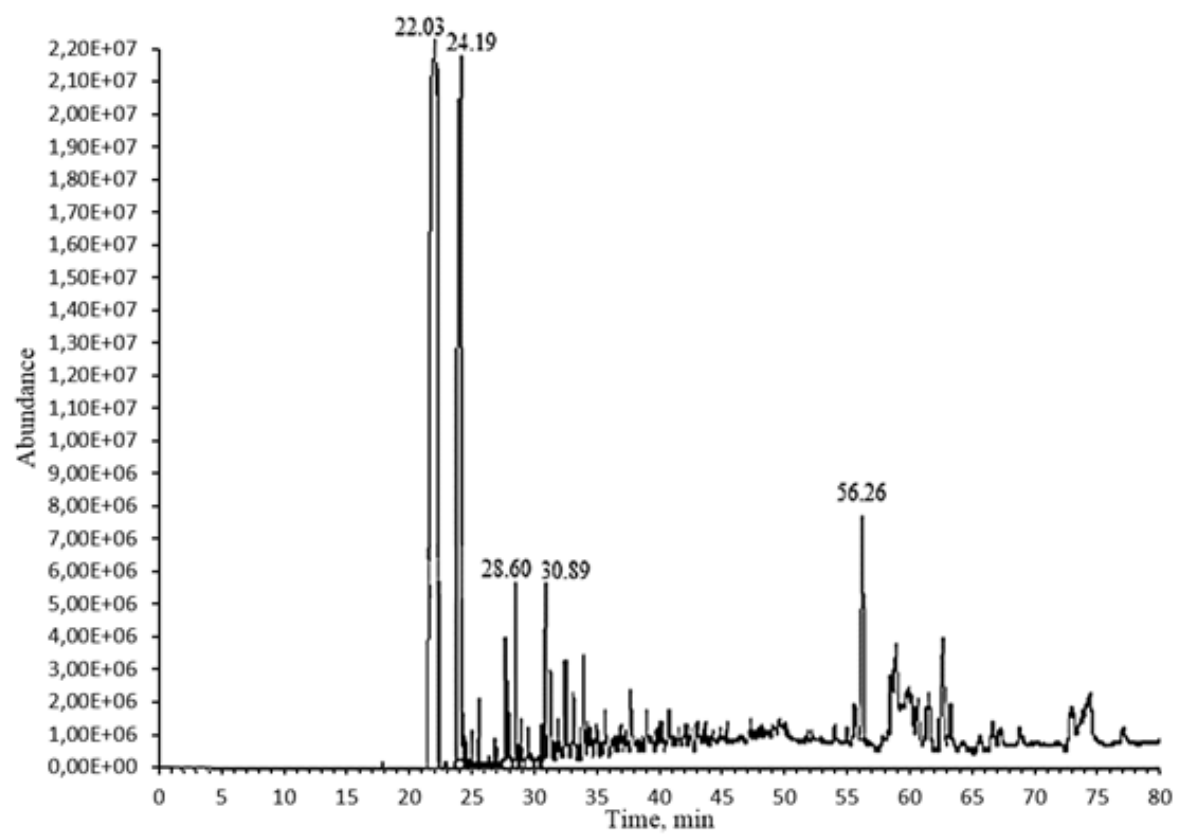

Fig. 10. GC-MS chromatogram of oils (Experiment 22).

Table 3. List of compounds belonging to peaks observed in the GC-MS chromatogram in Figure 10

\begin{tabular}{|l|c|l|c|c|}
\hline $\begin{array}{l}\text { Peak } \\
\text { No. }\end{array}$ & $\begin{array}{c}\text { RT, } \\
\text { min }\end{array}$ & Possible compound & $\begin{array}{c}\text { Similarity, } \\
\%\end{array}$ & $\begin{array}{c}\text { Amount in total } \\
\text { abundance, \% }\end{array}$ \\
\hline 1 & 22.03 & $\begin{array}{l}\text { Naphthalene, 1,2,3,4-tetrahydro- } \\
\text { Naphthalene }\end{array}$ & 97 & 53.247 \\
\hline & $\begin{array}{l}\text { 1,4-Dihydronaphthalene, } \\
\text { Naphthalene, 1,2-dihydro- } \\
\text { Naphthalene, } \\
\text { Cycloprop[a]indene, 1,1a,6,6a-tetr } \\
\text { ahydro- Cycloprop[a]indene }\end{array}$ & 95 & 94 \\
\hline
\end{tabular}


Table 3 (Continued)

\begin{tabular}{|c|c|c|c|c|}
\hline $\begin{array}{l}\text { Peak } \\
\text { No. }\end{array}$ & $\begin{array}{l}\mathrm{RT} \\
\min \end{array}$ & Possible compound & $\begin{array}{c}\text { Similarity, } \\
\% \\
\end{array}$ & $\begin{array}{l}\text { Amount in total } \\
\text { abundance, } \%\end{array}$ \\
\hline 3 & 24.19 & $\begin{array}{l}\text { Naphthalene, } \\
\text { 1H-Indene, 1-methylene- } \\
\text { 1H-Indene }\end{array}$ & $\begin{array}{l}97 \\
91\end{array}$ & 21.397 \\
\hline 4 & 25.68 & $\begin{array}{l}\text { Naphthalene, 1,2,3,4-tetrahydro-6- } \\
\text { methyl-Naphthalene, } \\
\text { Naphthalene, 1,2,3,4-tetrahydro-5- } \\
\text { methyl-Naphthalene }\end{array}$ & 97 & $\begin{array}{l}0.617 \\
96\end{array}$ \\
\hline 5 & 27.75 & $\begin{array}{l}\text { Naphthalene, 1-ethyl-1,2,3,4-tetra } \\
\text { hydro- Naphthalene, } \\
\text { Naphthalene, 5-ethyl-1,2,3,4-tetra } \\
\text { hydro- Naphthalene, } \\
\text { 1H-Indene, 1-ethyl-2,3-dihydro-1- } \\
\text { methyl-1H-Indene }\end{array}$ & $\begin{array}{l}91 \\
90 \\
78\end{array}$ & 1.242 \\
\hline 6 & 27.96 & $\begin{array}{l}\text { Naphthalene, 2-methyl- } \\
\text { Naphthalene, } \\
\text { 1-methyl-Naphthalene }\end{array}$ & 94 & $\begin{array}{l}0.937 \\
94\end{array}$ \\
\hline 7 & 28.60 & $\begin{array}{l}\text { Naphthalene, 1-methyl- } \\
\text { Naphthalene, } \\
\text { Naphthalene, 2-methyl- } \\
\text { Naphthalene, } \\
\text { 1,4-Methanonaphthalene, } \\
\text { 1,4-dihydro- } \\
\text { 1,4-Methanonaphthalene }\end{array}$ & 91 & 1.774 \\
\hline 8 & 30.74 & $\begin{array}{l}\text { Naphthalene, 1,2,3,4-tetrahydro-1, } \\
\text { 1,6-trimethyl- Naphthalene, } \\
\text { 2,3,6-Trifluoroacetophenone, } \\
\text { 2',4',5'-Trifluoroacetophenone }\end{array}$ & $\begin{array}{l}70 \\
59 \\
59\end{array}$ & 0.747 \\
\hline 9 & 30.89 & $\begin{array}{l}\text { Naphthalene, 1,2,3,4-tetrahydro-1- } \\
\text { propyl- Naphthalene, } \\
\text { 1-Phenyl-1-hexyn-3-ol, } \\
\text { Naphthalene, 5-ethyl-1,2,3,4-tetra } \\
\text { hydro- Naphthalene }\end{array}$ & $\begin{array}{l}94 \\
59 \\
53\end{array}$ & 1.809 \\
\hline 10 & 31.36 & $\begin{array}{l}\text { Naphthalene, 1-ethyl- } \\
\text { Naphthalene, } \\
\text { Naphthalene, 2-ethyl- Naphthalene }\end{array}$ & $\begin{array}{l}94 \\
91\end{array}$ & 1.117 \\
\hline 11 & 32.54 & $\begin{array}{l}\text { 1(2H)-Naphthalenone, 3,4-dihydro- } \\
1(2 \mathrm{H}) \text {-Naphthalenone }\end{array}$ & 95 & 1.137 \\
\hline 12 & 33.20 & $\begin{array}{l}\text { 2(1H)-Quinolinone, 1-methyl- } \\
\text { 2(1H)-Quinolinone, } \\
\text { 4,6-Quinolinediamine, } \\
\text { 2-Naphthalenol, 8-amino- } \\
\text { 2-Naphthalenol }\end{array}$ & $\begin{array}{l}53 \\
50 \\
47\end{array}$ & 1.094 \\
\hline
\end{tabular}


Table 3 (Continued)

\begin{tabular}{|c|c|c|c|c|}
\hline $\begin{array}{l}\text { Peak } \\
\text { No. }\end{array}$ & $\begin{array}{l}\text { RT, } \\
\text { min }\end{array}$ & Possible compound & $\begin{array}{c}\text { Similarity, } \\
\% \\
\end{array}$ & $\begin{array}{c}\text { Amount in total } \\
\text { abundance, } \%\end{array}$ \\
\hline 13 & 33.96 & $\begin{array}{l}\text { Naphthalene, 1,2,3,4-tetrahydro- } \\
\text { 1-propyl- Naphthalene, } \\
\text { Naphthalene, 5-ethyl-1,2,3,4-tetra } \\
\text { hydro- Naphthalene, } \\
\text { 1-Hexen-3-one, 5-methyl-1-phenyl- } \\
\text { 1-Hexen-3-one }\end{array}$ & $\begin{array}{l}81 \\
50 \\
45\end{array}$ & 1.005 \\
\hline 14 & & $\begin{array}{l}\text { 37.72 1,1'-Biphenyl, 3-methyl- } \\
\text { 1,1'-Biphenyl, } \\
\text { 1-Isopropenylnaphthalene, } \\
\text { 1,1'-Biphenyl, 2-methyl- } \\
\text { 1,1'-Biphenyl }\end{array}$ & $\begin{array}{l}83 \\
70 \\
64\end{array}$ & 0.368 \\
\hline 15 & 56.26 & $\begin{array}{l}\text { 5-Chloro-1,3-dimethylpyrazole, } \\
\text { 2-Acetoxytetralin, } \\
\text { Indole-3-pyruvic acid }\end{array}$ & 47 & $\begin{array}{l}5.389 \\
43 \\
43\end{array}$ \\
\hline 16 & 58.58 & $\begin{array}{l}\text { Naphthalene, 1,2,3,4-tetrahydro-1- } \\
\text { octyl- Naphthalene, } \\
\text { Naphthalene, 1-ethyl-1,2,3,4-tetra } \\
\text { hydro- Naphthalene, } \\
\text { 3-Chlorotricyclo[5.2.1.0(4,8)]deca } \\
\text {-2,5-diene }\end{array}$ & $\begin{array}{l}53 \\
43 \\
43\end{array}$ & 1.518 \\
\hline 17 & 58.92 & $\begin{array}{l}\text { Naphthalene, 1,2,3,4-tetrahydro-1- } \\
\text { octyl- Naphthalene, } \\
\text { 1H-Indene, 2,3-dihydro-1, } \\
\text { 6-dimethy 1-1H-Indene, } \\
\text { Naphthalene, 1-ethyl-1,2,3,4-tetra } \\
\text { hydro- Naphthalene }\end{array}$ & 38 & $\begin{array}{l}2.066 \\
38\end{array}$ \\
\hline 18 & 62.62 & $\begin{array}{l}\text { 2,2'-Binaphthalene, } 1,1^{\prime}, 2,2^{\prime}, 3,3^{\prime} \\
\text {,4,4'-octahydro-2,2'-Binaphthalene, } \\
\text { Naphthalene-4a,8a-dicarboxylic acid } \\
1,4,4 \mathrm{a}, 5,8,8 \mathrm{a}-\text { hexahydro-, dimethyl } \\
\text { ester, } \\
\text { 2-t-Butyl-6-methyl-5-(1-phenylbut- } \\
\text { 3-enyl)[1,3]dioxan-4-one }\end{array}$ & $\begin{array}{l}96 \\
50 \\
47\end{array}$ & 3.774 \\
\hline
\end{tabular}

The abbreviation used: RT:- retention time.

\section{Conclusions}

Based on the results of the study it can be concluded that tetralin/oil shale ratio had no considerable effect on the noncatalytic liquefaction of NiğdeUlukışla oil shale and the optimum ratio was $3 / 1$, proceeding from total and oil + gas conversions data. 
In the catalytic liquefaction of Niğde-Ulukışla oil shale, the highest catalytic activity in terms of total and liquefaction products conversions was obtained with $\mathrm{MoO}_{3}$ catalyst at a concentration of $9 \%$ by weight. As temperature increased from $350{ }^{\circ} \mathrm{C}$ to $400{ }^{\circ} \mathrm{C}$, total conversion increased slightly, but a further rise in temperature had no effect on the total conversion during 90 minutes of reaction time.

Since much lower liquefaction conversion of Niğde-Ulukışla oil shale under both noncatalytic and catalytic conditions was attained, its co-liquefaction with waste paper was performed at $400{ }^{\circ} \mathrm{C}$ in the presence of $\mathrm{MoO}_{3}$ catalyst and total and oil + gas conversion values were increased from 31.1 to $80.5 \%$ and from 27.8 to $70.0 \%$, respectively, at an oil shale/waste paper ratio of $1 / 1$.

Oil obtained as a liquid product from the liquefaction process of oil shale under catalytic conditions of experiment 22 consisted mainly of naphthalene and its derivatives and polycyclic hydrocarbon such as indene and its derivatives.

\section{Acknowledgements}

The authors would like to thank the Scientific and Technological Research Council of Turkey for financially supporting this project under Grant No TUBITAK-MAG 104M181.

\section{REFERENCES}

1. Shah, Y. T. Reaction Engineering in Direct Coal Liquefaction. Addison-Wesley Advanced Book Program, Reading, Massachusetts, 1981.

2. Liu, Z., Shi, S., Li, Y. Coal liquefaction technologies - Development in China and challenges in chemical reaction engineering. Chem. Eng. Sci., 2010, 65(1), $12-17$.

3. Stihle, J., Uzio, D., Lorentz, C., Charon, N., Ponthus, J., Geantet, C. Detailed characterization of coal-derived liquids from direct coal liquefaction on supported catalysts. Fuel, 2012, 95, 79-87.

4. Jiang, H., Deng, S., Chen, J., Zhang, M., Li, S., Shao, Y., Yang, J., Li, J. Effect of hydrothermal pretreatment on product distribution and characteristics of oil produced by the pyrolysis of Huadian oil shale. Energ. Convers. Manage., 2017, 143, 505-512.

5. Wu, T., Xue, Q., Li, X., Tao, Y., Jin, Y., Ling, C., Lu, S. Extraction of kerogen from oil shale with supercritical carbon dioxide: Molecular dynamics simulations. J. Supercrit. Fluid., 2016, 107, 499-506.

6. Lin, L., Lai, D., Guo, E., Zhang, C., Xu, G. Oil shale pyrolysis in indirectly heated fixed bed with metallic plates of heating enhancement. Fuel, 2016, 163, $48-55$.

7. Shi, W., Wang, Z., Song, W., Li, S., Li, X. Pyrolysis of Huadian oil shale under catalysis of shale ash. J. Anal. Appl. Pyrol., 2017, 123, 160-164. 
8. Zhao, X., Liu, Z., Liu, Q. The bond cleavage and radical coupling during pyrolysis of Huadian oil shale. Fuel, 2017, 199, 169-175.

9. Bai, F., Sun, Y., Liu, Y., Guo, M. Evaluation of the porous structure of Huadian oil shale during pyrolysis using multiple approaches. Fuel, 2017, 187, 1-8.

10. Pan, L., Dai, F., Li, G., Liu, S. A TGA/DTA-MS investigation to the influence of process conditions on the pyrolysis of Jimsar oil shale. Energy, 2015, 86, 749-757.

11. Abourriche, A. K., Oumam, M., Hannache, H., Birot, M., Abouliatim, Y., Benhammou, A., El Hafiane, Y., Abourriche, A. M., Pailler, R., Naslain, R. Comparative studies on the yield and quality of oils extracted from Moroccan oil shale. J. Supercrit. Fluid., 2013, 84, 98-104.

12. Al-Harahsheh, M., Al-Ayed, O., Robinson, J., Kingman, S., Al-Harahsheh, A., Tarawneh, K., Saeid, A., Barranco, R. Effect of demineralization and heating rate on the pyrolysis kinetics of Jordanian oil shales. Fuel Process. Technol., 2011, 92(9), 1805-1811.

13. Tiikma, L., Johannes, I., Luik, H., Zaidentsal, A., Vink, N. Thermal dissolution of Estonian oil shale. J. Anal. Appl. Pyrol., 2009, 85(1-2), 502-507.

14. Yanik, J., Yüksel, M., Sağlam, M., Olukçu, N., Bartle, K., $\quad$ Frere, B. Characterization of the oil fractions of shale oil obtained by pyrolysis and supercritical water extraction. Fuel, 1995, 74(1), 46-50.

15. Lin, Y., Liao, Y., Yu, Z., Fang, S., Lin, Y., Fan, Y., Peng, X., Ma, X. Co-pyrolysis kinetics of sewage sludge and oil shale thermal decomposition using TGA-FTIR analysis. Energ. Convers. Manage., 2016, 118, 345-352.

16. Hu, Z., Ma, X., Li, L. The synergistic effect of co-pyrolysis of oil shale and microalgae to produce syngas. J. Energy Inst., 2016, 89(3), 447-455.

17. Tiikma, L., Johannes, I., Luik, H., Gregor, A. Synergy in the hydrothermal pyrolysis of oil shale/sawdust blends. J. Anal. Appl. Pyrol., 2016, 117, 247-256.

18. Kılıç, M., Pütün, A. E., Uzun, B. B., Pütün, E., Converting of oil shale and biomass into liquid hydrocarbons via pyrolysis. Energ. Convers. Manage., 2014, 78, 461-467.

19. Johannes, I., Tiikma, L., Luik, H. Synergy in co-pyrolysis of oil shale and pine sawdust in autoclaves. J. Anal. Appl. Pyrol., 2013, 104, 341-352.

20. Aboulkas, A., Makayssi, T., Bilali, L., El harfi, K., Nadifiyine, M., Benchanaa, M. Co-pyrolysis of oil shale and High density polyethylene: Structural characterization of the oil. Fuel Process. Technol., 2012, 96, 203208.

21. Luik, H., Luik, L., Tiikma, L., Vink, N. Parallels between slow pyrolysis of Estonian oil shale and forest biomass residues. J. Anal. Appl. Pyrol., 2007, 79(1-2), 205-209.

22. Allawzi, M., Al-Otoom, A., Allaboun, H., Ajlouni, A., Al Nseirat, F. $\mathrm{CO}_{2}$ supercritical fluid extraction of Jordanian oil shale utilizing different cosolvents. Fuel Process. Technol., 2011, 92(10), 2016-2023.

23. Abourriche, A., Oumam, M., Hannache, H., Adil, A., Pailler, R., Naslain, R., Birot, M., Pillot, J.-P. Effect of toluene proportion on the yield and composition of oils obtained by supercritical extraction of Moroccan oil shale. J. Supercrit. Fluid., 2009, 51(1), 24-28.

24. El harfi, K., Bennouna, C., Mokhlisse, A., Ben chanâa, M., Lemée, L., Joffre, J., Amblès, A. Supercritical fluid extraction of Moroccan (Timahdit) oil shale with water. J. Anal. Appl. Pyrol., 1999, 50(2), 163-174. 
25. Yang, Q., Qian, Y., Kraslawski, A., Zhou, H., Yang, S. Advanced exergy analysis of an oil shale retorting process. Appl. Energ., 2016, 165, 405-415.

26. Chen, B., Han, X., Li, Q., Jiang, X. Study of the thermal conversions of organic carbon of Huadian oil shale during pyrolysis. Energ. Convers. Manage., 2016, 127, 284-292.

27. Hascakir, B., Babadagli, T, Akin, S. Experimental and numerical simulation of oil recovery from oil shales by electrical heating. Energ. Fuel., 2008, 22, 39763985.

28. Sinag, A., Canel, M. Comparison of retorting and supercritical extraction techniques on gaining liquid products from Göynük oil shale (Turkey). Energ. Source., 2004, 26(8), 739-749.

29. Tucker, J. D., Masri, B., Lee, S. A comparison of retorting and supercritical extraction techniques on El-Lajjun oil shale. Energ. Source., 2000, 22(5), $453-$ 463.

30. Hepbasl1, A. Oil shale as an alternative energy source. Energ. Source., 2004, 26(2), 107-118.

31. Altun, N. E., Hiçyılmaz, C., Hwang, J.-Y., Bağcı, A. S., Kök, M. V. Oil shales in the world and Turkey; reserves, current situation and future prospects: a review. Oil Shale, 2006, 23(3), 211-227.

32. Ekinci, E. Turkish oil shales potential for synthetic crude oil and carbon material production. International Conference on Oil Shale: "Recent Trends in Oil Shale”, 7-9 November 2006, Amman, Jordan, Paper No. rtos-A123.

33. Şengüler, İ., Kara-Gülbay, R., Korkmaz, S. Organic geochemical characteristics of Miocene oil shale deposits in the Eskişehir Basin, western Anatolia, Turkey. Oil Shale, 2014, 31(4), 315-336.

34. Metecan, İ. H., Sağlam, M., Yanık, J., Ballice, L., Yüksel, M. Effect of pyrite catalyst on the hydroliquefaction of Göynük (Turkey) oil shale in the presence of toluene. Fuel, 1999, 78(5), 619-622.

35. Olukcu, N., Yanik, J., Saglam, M., Yuksel, M. Liquefaction of Beypazari oil shale by pyrolysis. J. Anal. Appl. Pyrol., 2002, 64(1), 29-41.

36. Ballice, L. Effect of demineralization on yield and composition of the volatile products evolved from temperature-programmed pyrolysis of Beypazari (Turkey) oil shale. Fuel Process. Technol., 2005, 86(6), 673-690.

37. Karaca, H., Ceylan, K., Olcay, A. Catalytic dissolution of two Turkish lignites in tetralin under nitrogen atmosphere: effects of the extraction parameters on the conversion. Fuel, 2001, 80(4), 559-564.

38. Rodriguez, I. M., Chomon, M. J., Caballero, B., Arias, P. L, Legarreta, J. A. Liquefaction behaviour of a Spanish subbituminous A coal under different conditions of hydrogen availability. Fuel Process. Technol., 1998, 58(1), 17-24.

39. Wang, Z., Shui, H., Zhang, D., Gao, J. A comparison of FeS, FeS+S and solid superacid catalytic properties for coal hydro-liquefaction. Fuel, 2007, 86(5-6), 835-842.

40. Shui, H., Chen, Z., Wang, Z., Zhang, D. Kinetics of Shenhua coal liquefaction catalyzed by $\mathrm{SO}_{4}{ }^{2-} / \mathrm{ZrO}_{2}$ solid acid. Fuel, 2010, 89(1), 67-72.

41. Ishak, M. A. M., Ismail, K., Abdullah, M. F., Kadir, M. O. A., Mohamed, A. R., Abdullah, W. H. Liquefaction studies of low-rank Malaysian coal using highpressure high-temperature batch-wise reactor. Coal Prep., 2005, 25(4), 221237. 
42. Rafiqul, I., Lugang, B., Yan, Y., Li, T. Study on co-liquefaction of coal and bagasse by factorial experiment design method. Fuel Process. Technol., 2000, 68(1), 3-12.

43. Abnisa, F., Daud, W. M. A. W. A review on co-pyrolysis of biomass: An optional technique to obtain a high-grade pyrolysis oil. Energ. Convers. Manage., 2014, 87, 71-85.

Presented by J. Soone

Received April 9, 2016 